\title{
Determination of Hydroquinone in Some Pharmaceutical and Cosmetic Preparations by Spectrophotometric Method
}

\author{
Hawaa S. Elferjani ${ }^{1}$, Najw H. S. Ahmida ${ }^{2}$, Aziza Ahmida ${ }^{3}$ \\ ${ }^{1,2,3}$ Department of Chemistry, Faculty of Science, University of Benghazi, Libya 2017
}

\begin{abstract}
In This study thirteen skin lighting creams are available in Libyan markets in Benghazi and Pharmaceutical Preparations were used to determine the content of hydroquinone by a rapid and simple UV spectrophotometric procedures. The labels on the packages noticeably did not show the content of hydroquinone. All samples were analysed by a UV spectrophotometer, Beer's law was obeyed in the range of 10- $40 \mu \mathrm{g} / \mathrm{ml}$ at 290nm using $0.05 \mathrm{M} \mathrm{H}_{2} \mathrm{SO}_{4}$ as solvent with linear regression coefficient of 0.9994 . The results showed the concentration of hydroquinone in all cosmetic samples ranged from $0.008 \%$ to $0.210 \%$. The effect of time has been studied.
\end{abstract}

Keywords: hydroquinone, spectrophotometry, pharmaceutical and cosmetic preparations

\section{Introduction}

Hydroquinone is an aromatic organic compound of the phenol, a derivative of benzene having the chemical formula $\mathrm{C}_{6} \mathrm{H}_{4}(\mathrm{OH})_{2}$, figure ].<smiles>Oc1ccc(O)cc1</smiles>

Figure 1: Chemical structure of hydroquinone

It is occurs in nature in many different forms. It appears in the leaves and bark of certain berries like blueberries and cranberries. If tea is made from these leaves, it will then appear in the tea. It is in certain coffee beans and is therefore in certain coffees. It can also be found in various fruits and vegetables, and wheat. It can therefore also be found in wines and beers. Industrially, it is produced in several countries. In 1979, the total world capacity for production exceeded 40000 tonnes, while in 1992 it was approximately 35000 tonnes. It is extensively used as a reducing agent, as a photographic developer, as an antioxidant or stabilizer for certain materials that polymerize in the presence of free radicals, and as a chemical intermediate for the production of antioxidants, agrochemicals and polymers. Hydroquinone is also used in cosmetics and medical preparations. Hydroquinone is used as a topical application in skin whitening to reduce the colour of skin. Hyperpigmentation skin disorder is treated with hydroquinone products, this substance inhibits the tyrosinase enzyme which is responsible for the first reaction of melanin formation [1] Subsequently melanin decreases and skin becomes depigmented . It is known that hydroquinone is the most conventional skin whitening agent, however ,Clinical preparation containing 2-4\% hydroquinone are prescribed for the treatment of hyperpigmentation such as melisma, freckles and senile lentigines as well as chloasma. In addition, numerous studies revealed that, Hydroquinone has numerous unfavourable effects with long term applications including irritative dermatitis melanocyte destruction, contact dermatitis and ochronosis [2,3]. its use has been recommended to ban in cosmetics[4,5]; it is still being used in developing countries in skin lightening cosmetics. numerous studies point to hydroquinone as a likely carcinogen. Numerous studies show a high occurrence of tumors in rats who had been subjected to doses of hydroquinone, including thyroid follicular cell hyperplasias, anisokaryosis, mononuclear cell leukemia, hepatocellular adenomas, renal tubule cell adenomas. Hydroquinone toxicity can lead to severe side effects such as kidney and liver malfunction, blood poisoning, nausea, abdominal pains, convulsion and even coma. Animal test on rats, mice and rabbits showed that hydroquinone can cause acute toxicity, all of these potentially lethal results are possibilities with the use of too much hydroquinone. As a result of these tests the European Union has banned its use. However, Terer et. al. [6] reported the content of hydroquinone in Body lotions and creams sold in Retail outlet in Barton, Kenya. In this study twenty four body lotions and body creams were randomly sampled from the retail outlets within Baraton, the lables on the packages noticeably did not indicate the presence of hydroquinone. The level of hydroquinone for all samples creams was below $2 \%$ which is upper limit for cosmetic creams. Ansah and co-workers [7] studied the content of hydroquinone of skin toning creams and cosmetic soaps, in this study sixty -two skin lighting creams and soaps were analysed to detect the hydroquinone levels by high performance liquid chromatography. The mean concentration of total hydroquinone was $0.234 \pm 0.385$ and $0.035 \pm 0.021 \%$ in skin toning creams and cosmetic soaps. All the creams and soaps analysed had hydroquinone levels below the US food and Drug administration's accepted limited $1 \mu \mathrm{g} / \mathrm{g}$ and $2 \%$ respectively. hydroqunione is carcinogenic it has been banned in some countries because of fears of a cancer risk [8,9]. Hydroquinone has been used for decades as a skin lightening agent. Metabolites of hydroquinone formed in the liver, e.g., p-benzoquinone and glutathione conjugates of hydroquinone are the main cancercausing agents. In the bone marrow, hydroquinone is

Volume 6 Issue 7, July 2017 


\section{International Journal of Science and Research (IJSR) \\ ISSN (Online): 2319-7064}

Index Copernicus Value (2015): 78.96 | Impact Factor (2015): 6.391

oxidized into p-benzoquinone because of the high myeloperoxidase activity. Topically applied hydroquinonecontaining creams may give rise to accumulation of $\mathrm{p}$ benzoquinone and glutathione conjugates of hydroquinone. These compounds are also responsible for the DNA damage and mutations. They also have the capability to disrupt protective mechanisms, whereby they facilitate further development of cancer.

In the bone marrow, long-term effects such as aplastic anemia and acute myeloid leukemia may occur. Most of the evidence stems from research on benzene toxicity, which appears to arise via its metabolite hydroquinone. There is no report yet demonstrating carcinogenesis or other ill-effects resulting from the application of hydroquinone-containing creams. The fact that many countries around the world have banned Hydroquinone is no coincidence - hydroquinone based products have caused disfigurement and permanent scarring to hundreds of thousands of faces around the world. Dermatologists say prolonged use of Hydroquinone products destroys the skin's protective outer layer and may cause temporary or permanent discoloration of the skin. Ultimately, it can damage the nerves or even lead to kidney failure or skin cancer [10]. Neurological effects of hydroquinone include; headache, dizziness, tinnitus, delirium, muscle twitching, tremor, nausea, vomiting, and the production of green to brown-green urine may occur[11]

\section{Chemical and reagents}

All reagents were of analytical reagent grade $(\mathrm{BDH}$ Chemicals Ltd, Poole, England))

\section{Reagents required}

Sulphuric acid $(0.05 \mathrm{M})$,

\section{A Standard solution of Hydroquinone}

$(1.00 \mathrm{~g}, \mathrm{M} . \mathrm{W} .=110.112 \mathrm{~g} / \mathrm{mol})$ standard hydroquinone was dissolved in $1000 \mathrm{ml}$ of $0.05 \mathrm{M}$ sulphuric acid to make 1000 ppm

\section{Sampling}

In this study thirteen different brands of cosmetic cream randomly selected from Benghazi market, and three Pharmaceutical Preparations we are using the method proposed by (Oyedeji et al., 2009) to analyze the presence and exact concentration of Hydroquinone. For the samples, about accurately $1 \mathrm{~g}$ of each sample was dissolved in $20 \mathrm{~cm}^{3}$ of $0.05 \mathrm{M}$ Sulphuric acid in a water bath. This solution was then transferred into $25 \mathrm{~cm}^{3}$ standard volumetric flask and made to volume with the $0.05 \mathrm{M}$ sulphuric acid. The solution was then filtered with a filter paper then discarded the first 5 $\mathrm{cm}^{3}$. The filter paper was then rinsed with additional $5 \mathrm{~cm}^{3}$ of sulphuric acid to remove any retained sample. The concentration of hydroquinone was determined using a UV spectrophotometer at a wavelength of $290 \mathrm{~nm}$. using quartz cuvette.
Estimation of $\chi \max$ (maximum absorption of hydroquinone)

To determine the maximum absorption, standard solutions of hydroquinone in concentration of $40 \mathrm{ppm}$ were prepared. Scanning of the hydroquinone in a wavelength range from $250 \mathrm{~nm}$ to $320 \mathrm{~nm}$ showed a maximum absorbance ( $\chi \max )$ at $290 \mathrm{~nm}$ as shown in table (1) and figure( 2)

Table 1: Maximum absorbance wavelength $\left(\lambda_{\max }, \mathrm{nm}\right)$

\begin{tabular}{|c|c|}
\hline$\lambda(\mathrm{nm})$ & $\mathrm{A}$ \\
\hline 250 & 0.087 \\
\hline 260 & 0.134 \\
\hline 270 & 0.321 \\
\hline 280 & 0.645 \\
\hline 290 & 0.974 \\
\hline 295 & 0.792 \\
\hline 300 & 0.612 \\
\hline 310 & 0.065 \\
\hline 320 & 0.019 \\
\hline
\end{tabular}

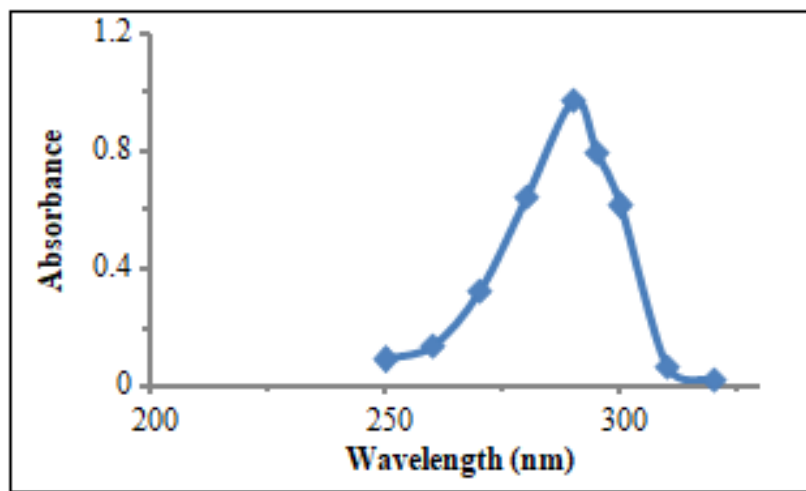

Figure 2: The absorption spectrum of hydroquinone solution $(40 \mu \mathrm{g} / \mathrm{ml})$ in $0.05 \mathrm{M} \mathrm{H}_{2} \mathrm{SO}_{4}$

The most important objective gets from fig. 2 is the detection of maximum wavelength $\left(\lambda_{\max }\right)$ for hydroquinone Which was $290 \mathrm{~nm}$. This $\lambda_{\max }$ is used for further quantitative spectrophotometric measurements. This $\lambda_{\max }$ for hydroquinone was similar to the wavelength used for other spectrophotometric measurements by different authors [1215]

\section{Calibration curve}

After determination of the maximum absorption of hydroquinone $(290 \mathrm{~nm})$ using spectrophotometer, The absorbance was then taken at a wavelength of $290 \mathrm{~nm}$ and traced on the calibration curve to give the concentration of hydroquinone in each samples. The calibration curve was obtained from Hydroquinone standard by serial dilutions of concentrations $10,15,20,25,30,35$ and $40 \mathrm{ppm}$. Under the optimum experimental conditions, a good linear correlation was obtained between the absorbance and hydroquinone concentration in the range from 10 to $40 \mu \mathrm{g} / \mathrm{ml}$, fig. 3 . 
International Journal of Science and Research (IJSR)

ISSN (Online): 2319-7064

Index Copernicus Value (2015): 78.96 | Impact Factor (2015): 6.391

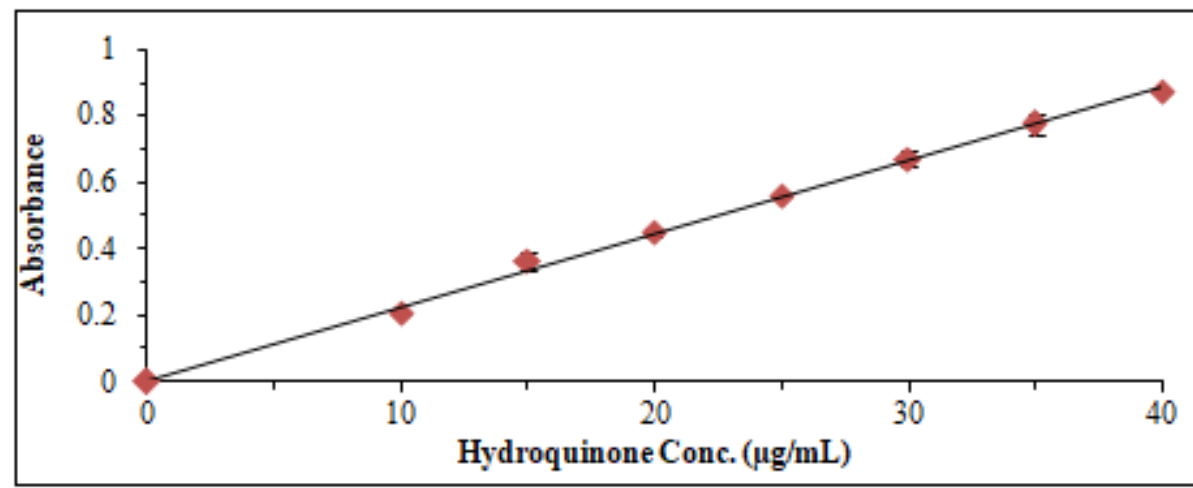

Figure 3: The calibration curve of hydroquinone $(10-40 \mu \mathrm{g} / \mathrm{ml})$ in $0.05 \mathrm{M} \mathrm{H}_{2} \mathrm{SO}_{4}$ solution at $290 \mathrm{~nm}$. The linear regression equation is $A=0.022 C+0.007\left(\mathrm{R}^{2}=0.997\right)$

From table 2; the parameters of the hydroquinone concentration-absorbance straight line were calculated by the least-squares method. The regression equation of the calibration line has the form:

$$
\begin{gathered}
A=0.022 C+0.007 \\
\left(\mathrm{R}^{2}=0.997\right) .
\end{gathered}
$$

where $C$ is the concentration of hydroquinone $(\mu \mathrm{g} / \mathrm{mL})$ and $A$ is the absorbance. The correlation coefficient $\left(\mathrm{R}^{2}\right)$ is 0.997. Statistical evaluation of the regression line using standard deviation about the regression $\left(S_{\mathrm{r}}\right)$, the standard deviation of intercept $\left(S_{a}\right)$ and standard deviation of the slop $\left(\mathrm{S}_{\mathrm{b}}\right)$ gave the following values: $1.60 \times 10^{-2}, 4.53 \times 10^{-4}$, and $1.14 \times 10^{-2}$ respectively. These small values point out low scattering of the point around the calibration curve and to the high precision of the method [16,17]. The limit of detection (LOD) was determined by establishing the minimum level at which the analyte can be detected. The LOD was found to be $2.358 \mu \mathrm{g} / \mathrm{mL}$, according to the $3 \mathrm{~s} / \mathrm{m}$ definition [43], where $\boldsymbol{s}$ is the standard deviation $(n=6)$ of the signal from $30 \mu \mathrm{g} / \mathrm{ml}$ hydroquinone aliquots, and $\boldsymbol{m}$ is the slop of the calibration graph. The limit of quantification (LOQ) was determined by establishing the lowest concentration that can be measured with acceptable accuracy and precision and was found to be $7.858 \mu \mathrm{g} / \mathrm{mL}$.

Table 2: Analytical data and the optical characteristics for the determination of Hydroquinone

\begin{tabular}{|c|c|}
\hline Parameter & $\begin{array}{c}\text { Analysis of } \\
\text { Hydroquinone }\end{array}$ \\
\hline$\lambda_{\max }$ & $290 \mathrm{~nm}$ \\
\hline Linear range & $10-40 \mu \mathrm{g} / \mathrm{mL}$ \\
\hline Linear regression equation $(\mathrm{A}=\mathrm{mC}+\mathrm{a})$ & \\
\hline Intercept $(a)$ & 0.007 \\
\hline Slop $(b)$ & 0.022 \\
\hline Correlation coefficient $\left(R^{2}\right)$ & 0.997 \\
\hline Limit of detection & $2.358 \mu \mathrm{g} / \mathrm{mL}$ \\
\hline Limit of quantification & $7.858 \mu \mathrm{g} / \mathrm{mL}$ \\
\hline
\end{tabular}

\section{Molar Absorptivity}

Whereas molar absorptivity it is very important characteristic to see how accurate and sensitive method. Molar absorptivity was measured at different concentration at $290 \mathrm{~nm}$ It was average $\left(2444.974 \mathrm{Mol}^{-1} \mathrm{Cm}^{-1} \mathrm{~L}\right)$ as shown in table 3

Table 3: Molar absorptivity of hydroquinone at different

\begin{tabular}{|c|c|c|c|c|}
\hline $\mathrm{C}_{\mu \mathrm{g} / \mathrm{ml}}$ & $\mathrm{Cg} / \mathrm{L}$ & $\mathrm{C} \mathrm{Mol} / \mathrm{L}$ & $\mathrm{A}$ & $\epsilon \mathrm{Mol}^{-1} \mathrm{Cm}^{-1} \mathrm{~L}$ \\
\hline 10 & 0.01 & $9.09091 \mathrm{E}-05$ & 0.208 & 2288 \\
\hline 15 & 0.015 & 0.000136364 & 0.339 & 2486 \\
\hline 20 & 0.02 & 0.000181818 & 0.447 & 2458.5 \\
\hline 25 & 0.025 & 0.000227273 & 0.555 & 2442 \\
\hline 30 & 0.03 & 0.000272727 & 0.678 & 2486 \\
\hline 35 & 0.035 & 0.000318182 & 0.788 & 2476.571 \\
\hline 40 & 0.04 & 0.000363636 & 0.901 & 2477.75 \\
\hline \multicolumn{4}{|c|}{ Mean } & 2444.974 \\
\hline
\end{tabular}
concentration at290nm

\section{Stability Study}

Hydroquinone is an organic compound belongs to phenolic group. It is alike the most compounds of this group, easily undergoes oxidative degradation particularly; in presence of metallic ions, high concentration of oxygen; high $\mathrm{pH}$ and exposure to light [18].

Therefore, the stability of hydroquinone solution is a critical parameter. In this study, the stability of hydroquinone standard solution is evaluated by measuring the absorbance of different concentrations of hydroquinone solutions in sulphuric acid at $290 \mathrm{~nm}$ within 21 days. However, the hydroquinone standards solution were kept in a dark at room temperature. The time (days) versus the absorbance corresponding to each concentration of hydroquinone was plotted, as illustrated in fig 4. This figure shows that the absorption response, corresponding to each concentration, remained constant within three weeks. Fig 4, also indicated that stability of hydroquinone standard solution could be even longer. 


\section{International Journal of Science and Research (IJSR) \\ ISSN (Online): 2319-7064}

Index Copernicus Value (2015): 78.96 | Impact Factor (2015): 6.391

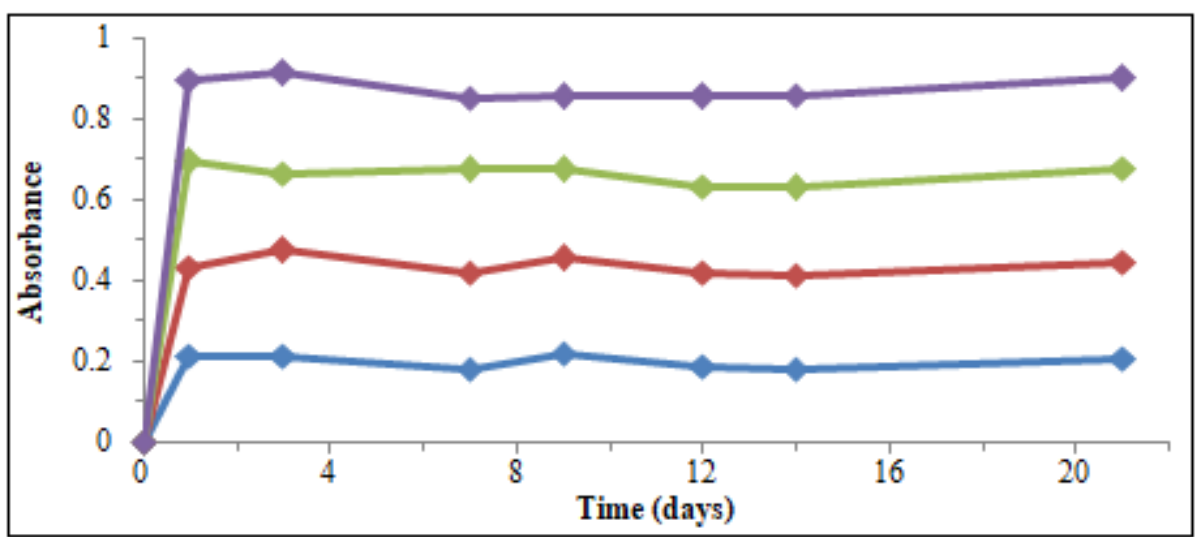

Figure 4: Absorbance versus time graphs for different concentrations of hydroquinone, $10 \mu \mathrm{g} / \mathrm{mL}(\diamond), 20 \mu \mathrm{g} / \mathrm{mL}(\diamond), 30$ $\mu \mathrm{g} / \mathrm{mL}(\diamond)$ and $40 \mu \mathrm{g} / \mathrm{mL}(\diamond)$.

\section{Practical Application}

After estimation (identifying the maximum wavelength for absorption measurement and obtained the best working range for hydroquinone in standard solution, the method was applied for quantitative determination of hydroquinone in some pharmaceutical creams and skin lighting cosmetics. The result obtained for selected measuring concentration of hydroquinone is given are given in table 4 and 5 respectively and Figures 5 and 6 .

\section{Analysis of Pharmaceutical Preparations:}

The spectrophotometric method has been applied to determine the concentration of hydroquinone in some pharmaceutical creams, that known in the market. In this project, the commercially pharmaceutical Creams of hydroquinone $\left(\right.$ Kinon $^{\circledR}$, Eldoquin ${ }^{\circledR}$ and Alphahydroquinon ${ }^{\circledR}$ creams) were determined directly by measuring the absorbance of the sample solution after the required digestion, filtration and dilution steps. In these studies, the level of hydroquinone is detected at $2.65 \%, 2.89 \%$ and $1.92 \%$ for Kinon, Eldoquin and Alpha hydroquinone respectively (table 4). The hydroquinone concentration in all selected pharmaceutical creams were within the acceptance level permitted by WHO.

Table 4: Application of the spectrophotometric method for determination of hydroquinone in pharmaceutical creams

\begin{tabular}{|c|c|c|}
\hline Preparation & $\begin{array}{c}\text { Found } \\
(\mu \mathrm{g} / \mathrm{mL})^{a b}\end{array}$ & Found $(\mathrm{g} \%)^{c}$ \\
\hline $\begin{array}{c}\text { KINON }^{\circledR} \text { WHITENING CREAM } \\
\text { (hydroquinone 2\%), Alkhuraiji }^{c}\end{array}$ & $33.48 \pm 2.23$ & $2.65 \pm 0.20$ \\
Factory Industrial Permission $_{\text {Riyadh-Kingdom of Saudi Arabia }}$ & & \\
\hline $\begin{array}{c}\text { ELDOQUIN }^{\circledR} \text { 2\% CREAM } \\
\text { (hydroquinone 2\%), ICN } \\
\text { Pharmaceuticals, Inc, Costa Mesa, } \\
\text { CA, USA }\end{array}$ & $36.27 \pm 3.31$ & $2.89 \pm 0.27$ \\
\hline $\begin{array}{c}\text { Hydroquinone Alpha 2 Cream, } \\
\text { Turkey }\end{array}$ & $24.18 \pm 0$ & $1.92 \pm 0.0$ \\
\hline
\end{tabular}

${ }^{a}$ Mean of 6 values.

${ }^{b}$ amount calculated using calibration curve.

${ }^{c} \mathrm{~g} \%=$ [Amount found $(\mu \mathrm{g} / \mathrm{mL}) /$ sample weigth $\left.\times 25\right]$

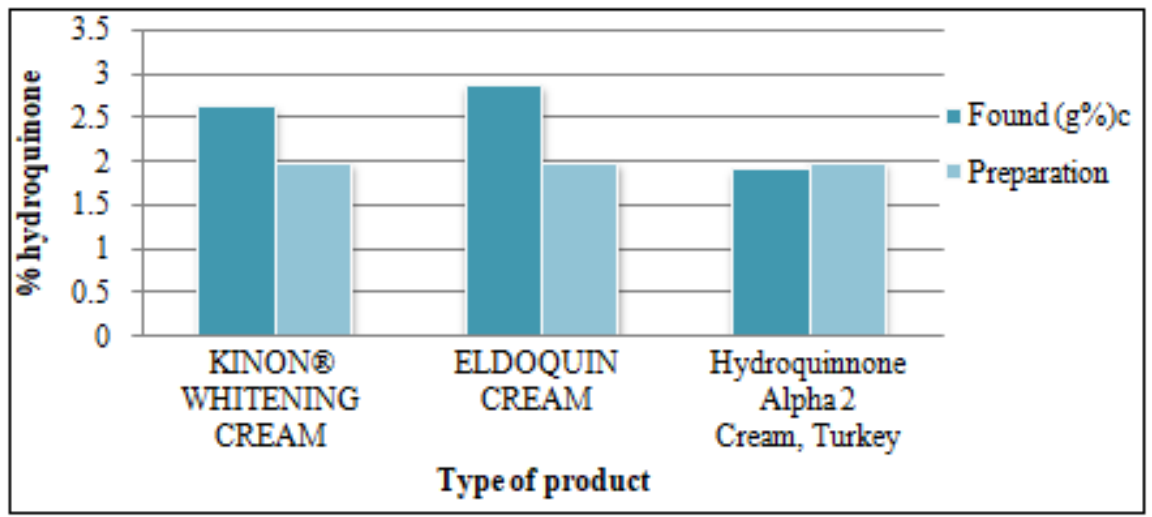

Figure 5: Illustrate Amount hydroquinone for calculated and labelled in g\%

Analysis of cosmetics

Various skin whiting creams were collected from local markets. The concentrations of hydroquinone in the selected cosmetic samples were ranged from $0.0077 \%$ to $0.21 \%$ as shown in table 5 and figure 6 . The level of hydroquinone in the samples was less than $2 \%$, which is level permitted by WHO [15]. 


\section{International Journal of Science and Research (IJSR) \\ ISSN (Online): 2319-7064 \\ Index Copernicus Value (2015): 78.96 | Impact Factor (2015): 6.391}

Table 5: Analysis of Hydroquinone in Some Skin whitening Cosmetics by the spectrophotometric method

\begin{tabular}{|c|c|c|}
\hline Preparation & $\begin{array}{c}\text { Found } \\
(\mu \mathrm{g} / \mathrm{mL})\end{array}$ & $\begin{array}{c}\text { Found } \\
(\mathrm{g} \%)\end{array}$ \\
\hline Spotless Face Cream, Eva cosmetic Co. Egypt. & 29.38 & 0.073 \\
\hline Fair\& Lovely, Hindustan Unilever Limited brand, India & 31.87 & 0.080 \\
\hline Flormar BB made in Turkey & 6.84 & 0.017 \\
\hline Nivea For men made in Germany & 21.33 & 0.053 \\
\hline Olay made in U.S.A & 44.44 & 0.210 \\
\hline Nivea for Woman Made in Germany & 3.07 & 0.008 \\
\hline Garnier made in Egypt & 27.20 & 0.140 \\
\hline Essence BB made in Italy & 32.62 & 0.081 \\
\hline NeoRetin Made in Spain & 25.156 & 0.063 \\
\hline Fair and lovely herbel balance & & \\
Made in India & 27.956 & 0.069 \\
\hline Garneir BB Made in France & 35.689 & 0.089 \\
\hline Hyalufactor made in Switzerland & 7.333 & 0.018 \\
\hline Shirley made in Tawan & 14.622 & 0.037 \\
\hline
\end{tabular}



Figure 6: Illustrate level of hydroquinone in cosmetic samples

When the comparison is made with previous studies found that the concentration range of hydroquinone. The level of hydroquinone was below $2 \%$ for seven of the creams, between $2-5 \%$ for two and above $5 \%$ for one. (The upper limit for cosmetic creams is 2 and $5 \%$ for therapeutic use) [19]. However, Terer et. al. reported the content of hydroquinone in Body lotions and creams sold in Retail outlet in Barton, Kenya. In this study twenty four body lotions and body creams were randomly sampled from the retail outlets within Baraton, the labels on the packages noticeably did not indicate the presence of hydroquinone. The level of hydroquinone for all samples creams was below $2 \%$ which is upper limit for cosmetic creams. (0.00009$0.03475)$ [20]

\section{Conclusion}

In our group Thirteen Skin whiting creams in Libyan market and three Pharmaceutical Preparations, have been analysed to determine the content of hydroquinone on it by using spectrophotometric method. The suitable wave length is 290 $\mathrm{nm}$. Beer's law was obeyed in the range of $10-40 \mu \mathrm{g} / \mathrm{ml}$ at $290 \mathrm{~nm}$ with linear regression coefficient of 0.9994 . The results showed the concentration of hydroquinone in all cosmetic samples ranged from $0.008 \%$ to $0.210 \%$. From the investigation, it is evident that most of creams contain small amounts of hydroquinone that are within the acceptable range. Therefore these levels may not cause permanent skin damage, disfigurement nor are carcinogenic.

\section{References}

[1] Palumbo A., Ischia M., Misuraca G., and Prota G. (1991) 'Mechanism of inhibition of melanogenesis by hydroquinone', Biochim. Biophys. Acta, 1073, 85-90.

[2] Adebajo S. (2002) "An Epidermiological Survey of the Use of Cosmetic Skin Lightening Cosmetics among Traders in Lagos, Nigeria," West African Journal of Medicine, 21, 51-55.

\section{Volume 6 Issue 7, July 2017 www.ijsr.net}




\section{International Journal of Science and Research (IJSR) \\ ISSN (Online): 2319-7064}

Index Copernicus Value (2015): 78.96 | Impact Factor (2015): 6.391

[3] Hardwick N. 'Exogenous Ochronosis (1989) An Epider-miological Study'British Journal of Dermatology'120( 2), 229-238.

[4] Twenty Fourth Directive 2000/6/EG Publication nr L056. European Union, (2000). Food and Drug Administration, "Skin Bleaching Drug.

[5] Federal Register, (2006) "Proposed Rules," 71( 167), 51146-51155.

[6] Terer E., Magut H. and Shadrack M. (2013), Baraton interdisplinary Research Journal , 3(1),23-28

[7] Agorku E., waansa-Ansah E. , Voegborlo R. , Amegbletor P., Springer Plus. (2016), 5: 316

[8] DH. Hutson, BJ. Dean, TM. Brooks. Genetic toxicology testing of 41 industrial chemicals. Research (1999);153:57-77.

[9] Engasser P., Maibach H. (2003) ' Cosmetics and dermatology'. J Am Acad Dermatol 5: 143-147.

[10] Westerhof W., Kooyers, (2005), ' Hydroquinone and its analogues in dermatology - a potential Health risk' Journal of Cosmetic Dermatology 4, 55-59

[11] Melisa C., and Jay W. (2009), ' FDA Proposes Hydroquinone Bans' Journal of Culture and Africa Women Studie ,14, 5-16

[12] Kipngetich T. E., Hillary M. and Shadrack M.( 2013) "UV-VIS Analysis and Determination of Hydroquinone in Body Lotions and Creams Sold in Retall outlets in Baraton, Kenya "Baraton Interdisplinary Research Journal, 3(1), 23-28.

[13] Siddique S., Parveen Z., Ali Z., Zaheer M.( 2012) "Qualitative and Quantitative Estimation of Hydroquinone in Skin Whitening Cosmetics" Journal of Cosmetic, Dermatological Sciences and Applications 2, 224-228.

[14] Khoshneviszadeh R., Bazza Z. B. S. F., Housaindakht M. R., Habiba A. E. and Rajabi O. (2015) "UV Spectrophotometric Determination and Validation of Hydroquinone in Liposome" Iranian Journal of Pharmaceutical Research, 14(2), 473-478.

[15] Odumasu P. O. and Elkwe T. O.( 2010) "Identification and Spectrophotometric Determination of Hydroquinone Levels in Some Cosmetic Creams" African Journal of Pharmacy and Pharmacology 4(5), 231-234.

[16] Miller J. C. and Miller J. N., 1993 "Statistics For Analytical Chemistry", 3rd ed., Ellis Horwood PTR Prentice Hall, England, 102.

[17] Harvey D. "Modern Analytical Chemistry" 2000, McGraw-Hill Higher Education, USA, pp 117-124

[18] Carcia P. L. G., Santoro M. I. R. M., Singh A. K., Kedor-Hachmann E. R. M.( 2007) "Determination of Optimum Wavelength and Dervative order in Spectrophotometry for Quantitative of Hydroquinone in Creams" Brazilian Journal of Pharmaceutical Sciences, 43(3), 397-404

[19] Odumosu P. and Ekwe T. (2010) 'dentification and spectrophometric determination of hydroquinone levels in some cosmetic creams' Vol. 4(5), pp. 231-234.

[20] Terer E., Magut H. and Shadrack,Baraton M. (2013) ' interdisplinary Research Journal 3(1),23-28

Volume 6 Issue 7, July 2017 www.ijsr.net 